\title{
Adjusting the Lens: Comparison of Focus Group and Survey Data in Iden- tifying and Addressing Issues of Diversity and Inclusion in Undergraduate Engineering Programs
}

\section{Dr. Amy Trauth, University of Delaware}

Amy Trauth, Ph.D., is the Senior Associate Director of Science Education at the University of Delaware's Professional Development Center for Educators. In her role, Amy works collaboratively with K-12 science and engineering teachers to develop and implement standards-based curricula and assessments. She also provides mentoring and coaching and co-teaching support to K-12 teachers across the entire trajectory of the profession. Her research focuses on teacher education, classroom assessment, and P-16 environmental and engineering education.

\section{Prof. Jenni Buckley, University of Delaware}

Dr. Buckley is an Associate Professor of Mechanical Engineering at University of Delaware. She received her Bachelor's of Engineering (2001) in Mechanical Engineering from the University of Delaware, and her MS (2004) and PhD (2006) in Mechanical Engineering from the University of California, Berkeley, where she worked on computational and experimental methods in spinal biomechanics. Since 2006, her research efforts have focused on the development and mechanical evaluation of medical and rehabilitation devices, particularly orthopaedic, neurosurgical, and pediatric devices. She teaches courses in design, biomechanics, and mechanics at University of Delaware and is heavily involved in K12 engineering education efforts at the local, state, and national levels.

\section{Dr. Sarah Ilkhanipour Rooney, University of Delaware}

Sarah I. Rooney is an Assistant Professor and Director of the Undergraduate Program in the Biomedical Engineering department at the University of Delaware, where she seeks to bring evidence-based teaching practices to the undergraduate curriculum. She received her B.S.E. (2009) and M.S.E. (2010) in Biomedical Engineering from the University of Michigan (Ann Arbor) and her Ph.D. (2015) in Bioengineering from the University of Pennsylvania.

\section{Prof. Joshua A. Enszer, University of Delaware}

Dr. Joshua Enszer is an associate professor in Chemical and Biomolecular Engineering at the University of Delaware. He has taught core and elective courses across the curriculum, from introduction to engineering science and material and energy balances to process control, capstone design, and mathematical modeling of chemical and environmental systems. His research interests include technology and learning in various incarnations: electronic portfolios as a means for assessment and professional development, implementation of computational tools across the chemical engineering curriculum, and game-based learning.

\section{Dr. Tia Navelene Barnes, University of Delaware}

Dr. Tia Barnes is an assistant professor at the University of Delaware in the Department of Human Development and Family Sciences and the Center for Research in Education and Social Policy. She is a mixed-methods researcher with a focus on the use of culturally responsive practices in creating positive classroom and school climates across grade levels. She has published work in several journals authored a number of research articles in journals including Aggression and Violent Behavior, Journal of School Violence, Journal of Classroom Interactions, and Education and Treatment of Children. She has also published book chapters in The Wiley Handbook of Violence and Aggression: Assessment, Prevention, and Treatment of Individuals and Classroom Behavior, Contexts, and Interventions: Advances in Learning and Behavioral Disabilities.

\section{Dr. Rachel Davidson, University of Delaware}

Professor, Dept. of Civil and Environmental Engineering Associate Dean for Diversity, College of Engineering Core Faculty Member, Disaster Research Center University of Delaware Newark, DE 


\title{
ADJUSTING THE LENS: COMPARISON OF FOCUS GROUP AND CROSS-SECTIONAL SURVEY DATA IN IDENTIFYING AND ADDRESSING ISSUES OF DIVERSITY AND INCLUSION IN UNDERGRADUATE ENGINEERING PROGRAMS
}

\author{
Amy E. Trauth, $\mathrm{PhD}^{1}$, Jenni M. Buckley, $\mathrm{PhD}^{2,1}$ \\ Sarah Rooney, $\mathrm{PhD}^{2}$, Joshua Enszer, $\mathrm{PhD}^{2}$, Tia N. Barnes, $\mathrm{PhD}^{1}$, Rachel Davidson, $\mathrm{PhD}^{2}$ \\ ${ }^{1}$ University of Delaware, College of Education and Human Development \\ ${ }^{2}$ University of Delaware, College of Engineering
}

\section{Introduction}

The underrepresentation of women and underrepresented minorities (URM, def. non-White, nonAsian) in engineering undergraduate programs can be attributed to a multitude of factors, including, but not limited to, insufficient access to high-quality curriculum and instruction and barriers in recruiting into engineering programs at the K-12 level, low self-efficacy, lack of peer support, inadequate academic advising or faculty support, harmful stereotypes of particular groups that influence interactions in classrooms or in peer groups, and a chilly or unappealing climate [1-9]. The contribution of each of these potential factors to issues of diversity and inclusion differs by institution and, frequently, within each institution due to the presence of microclimates across specific academic units and disciplines [10, 11].

Given potential granularity of the problem within and across institutions, it is important for faculty and administrators to assess issues of diversity and inclusion as proximal as possible to their own academic units, while simultaneously taking a sufficiently wide lens on the issues in order to avoid selection bias and confidentiality concerns [11]. Previous institutional research on underrepresentation in engineering utilized either a "tight lens" via focus group and one-on-one interviews $[2,12]$ or a "wide lens" through surveys $[5,6]$. Taken together, these studies have identified the primary drivers of underrepresentation in engineering [1,3]; however, they do not necessarily present a methodological framework for investigating issues at the institution level. Specifically, studies of diversity in engineering have yet to address the issue of "lens" - in other words, how does who you study and the level of analysis that is undertaken affect the findings and the implications that can be drawn?

The goal of this study was to compare common themes in diversity [1-9] that arise through focus group ("tight lens") and survey ("wide lens") methodologies within a single engineering undergraduate population. Our study was guided by the following research question: To what extent do fine granular (i.e., focus groups) and large granular (i.e., surveys) yield similar findings regarding the experiences of women and URMs in engineering? These data will aid in the interpretation of past and future ethnographic research on diversity and inclusion within engineering, specifically as it relates to the concordance of these two commonly used research methodologies. 


\section{Methods}

This study was guided by a sequential exploratory mixed methods design [13]. "Tight lens" and "wide lens" data collection methods were applied to the same undergraduate engineering student population at a single institution, which is a Research I land and sea grant university in the eastern United States. The "tight lens" approach involved multiple focus groups disaggregated by gender, race, and engineering discipline. Our focus group study methodology and results have already been published [11] and will be briefly summarized here. Focus group prompts were generated from the literature $[1,3]$ and included high school preparation, interactions with peers, interactions with faculty and staff, program supports, and family support. Focus group interviews were recorded, transcribed, and subjected to thematic analysis [14] (NVivo, QSR International). The analysis specifically focused on elucidating differences between majority (white or Asian male) and minority (women, URM) student experiences in each thematic area.

The "wide lens" approach involved administration of a voluntary survey (see survey items in Table 2) to the entire engineering undergraduate student body. The survey included items from validated instruments specific to engineering undergraduates for self-efficacy with math and science skills, engineering application, and hands-on prototyping [15-17]. Custom items were also included that built upon the five aforementioned themes from the focus group study [11]. The survey was administered electronically (Qualtrics, Provo, UT) to all engineering disciplines and grade bands over the course of two weeks in Spring 2018. Survey responses were compared by gender (male, female) and race (URM or majority) using one-way ANOVA with post-hoc adjustment (JMP Pro, SAS Institute).

\section{Results}

A total of 63 students participated in the focus group study $(2.6 \%$ total undergraduate population). Women and URMs were slightly oversampled, and all engineering disciplines were represented. As previously reported [11], the focus group study highlighted differential experiences for women and URM students versus their majority peers (Table 1). Specifically, both women and URMs reported being the target of peer micro-aggressions, and URMs experienced clear micro-aggressions from faculty members. All students reported insufficient high school preparation in fundamental STEM coursework, and family networks were seen universally as a major source of support. Many students cited financial concerns, with the issue being most acute amongst first-gen and URM student groups.

For the cross-sectional survey, the response rate was $10 \%$ of the student body population $(n=246)$. Survey respondents were demographically representative of the at-large population by race (13.5\% survey respondents vs. $10.5 \%$ population), and women were slightly overrepresented (40.8\% survey respondents vs. $24.1 \%$ population). Survey results indicated differential experiences by gender and race across several thematic areas (Table 2). In terms of professional identity, women, but not URMs, rated themselves lower in science, engineering, and problem solving self-efficacy as compared to their majority peers. Women were more hesitant than majority peers to approach a faculty member for help, to ask questions in class, and to participate in class discussions. Women also experienced significantly higher self-reported stress levels related to workload and modestly more stress related to financial concerns. URMs were less likely to cite sufficient financial aid opportunities and reasonable workload as positive influencers, but their self-reported stress levels related to workload and financial concerns were 
no different than majority students. Both women and URMs did report higher incidents of both experiencing and observing others experiencing peer-to-peer micro-aggressions; however, micro-aggressions were uniformly rare for peer-to-peer interactions as well as faculty-to-student interactions.

Table 1: Results from thematic analysis of focus group data. Focused group results previously presented in [11].

\begin{tabular}{|c|c|c|}
\hline Theme & Focus Group Population & Differential for Minority Students \\
\hline $\begin{array}{l}\text { High School } \\
\text { Preparation }\end{array}$ & $\begin{array}{l}\text { - Insufficient prior exposure in basic math } \\
\text { \& science courses } \\
\text { - Differential access to STEM-focused } \\
\text { extracurricular activities }\end{array}$ & \\
\hline Peer Interactions & $\begin{array}{l}\text { - "Weed out" culture within certain } \\
\text { departments negatively affects peer-to-peer } \\
\text { interactions } \\
\text { - Chilly climate within informal learning } \\
\text { environments, e.g., study work groups \& } \\
\text { project teams } \\
\text { - Formal \& informal peer networks seen as } \\
\text { highly beneficial }\end{array}$ & $\begin{array}{l}\text { - Micro-aggressions against women } \\
\text { \& URMs } \\
\text { - Black students, but not Latinx, report } \\
\text { lack of cultural awareness \& isolation } \\
\text { - Peer networks seen as more important } \\
\text { for women \& URMs }\end{array}$ \\
\hline $\begin{array}{l}\text { Faculty } \\
\text { Interactions }\end{array}$ & $\begin{array}{l}\text { - Mixed reviews on instructional \& } \\
\text { mentoring experiences } \\
\text { - Some faculty promote "weed-out" culture } \\
\text { \& chilly climate }\end{array}$ & $\begin{array}{l}\text { - Micro-aggressions by faculty against } \\
\text { women \& URMs } \\
\text { - URMs more conscious of lack of } \\
\text { diversity amongst faculty }\end{array}$ \\
\hline $\begin{array}{l}\text { Professional } \\
\text { Identity }\end{array}$ & $\begin{array}{l}\text { - Design projects \& internships help } \\
\text { students see themselves as engineers }\end{array}$ & $\begin{array}{l}\text { - Mixed perceptions of how being a woman } \\
\text { and/or URM impacts engineering identity }\end{array}$ \\
\hline Family Supports & $\begin{array}{l}\text { - Family seen as a source of emotional } \\
\text { support to persist in engineering } \\
\text { - Financial stressors related to tuition, } \\
\text { completing degree on time, and keeping } \\
\text { merit-based scholarships }\end{array}$ & $\begin{array}{l}\text { - First-gen and URM groups highlighted } \\
\text { financial concerns }\end{array}$ \\
\hline
\end{tabular}


Table 2: Results from cross-sectional survey of undergraduate engineering student body. Differential experiences by race and gender are presented only when statistically significant ( $\mathrm{p}<0.05$, one-way ANOVA). Table continued, overleaf.

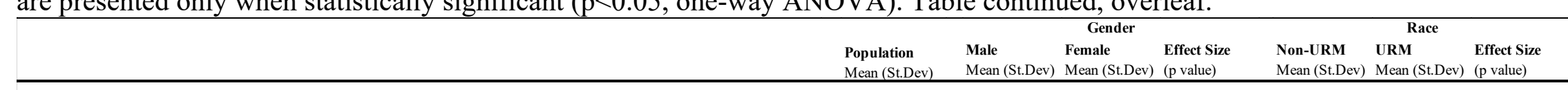

High School Preparation

Do you feel your high school coursework adequately prepared you to be successful in an engineering curriculum? [3] Yes, [2]

Somewhat, [1] No

$2.27(0.75$

Number of High School Engineering Co or Extra-Curricular Programs Participated

$1.57(1.34)$

\section{Peer Interactions}

To what extent do you agree with the following statements about your engineering courses?

[5] Strongly agree, [4] Agree, [3] Neither agree nor disagree, [2] Disagree, [1] Strongly disagree

- I can relate to the people around me in my class

- I have a lot in common with other students in my class.

- The other students in my class share my personal interests.

$2.88(1.28)$

$2.81(1.24)$

$2.96(1.29) \quad 2.60(1.11) \quad 0.35(0.03)$

- I can relate to the people around me in my extracurricular activities.

$2.85(1.29)$

Please indicate the degree to which each factor has positively influenced your decision to stay in your major [4] Significant Influence,

[3] Moderate Influence, [2] Small Influence, [1] No Influence

- Positive interactions with other engineering or computer science students

- Positive experiences in design teams or other collaborative learning experiences in engineering or computer science

- Friendly climate in engineering or computer science class

How often did the following occur in your experience as a student in [computer science or engineering] courses? [4] Almost Always,

[3] Often, [2] Occasionally, [1] Almost Never

- I observed other students being ignored or excluded because of their backgrounds or identities

- I was harassed or discriminated against by others in my major because of my background or identity.

$1.34(0.69)$

$1.25(0.62) \quad 1.45(0.78)-0.20(0.03)$

$1.29(0.67) \quad 1.64(0.82) \quad 0.35(0.008)$

Faculty Interactions
Please indicate the degree to which each factor has positively influenced your decision to stay in your major. [4] Significant Influence,

[3] Moderate Influence, [2] Small Influence, [1] No Influence

- Engineering or computer science faculty/department personnel show an interest in me

- Reasonable workload of engineering classes

$2.39(1.06)$

$2.52(1.03)$

$2.25(0.94)$

$1.95(0.94)$

- Good teaching by engineering and computer science faculty, instructors, or graduate assistants

- Effective academic advising by engineering or computer science faculty or advisors

How often did the following occur in your experience as a student in [computer science or engineering] courses? [4] Almost Alwavs,

[3] Often, [2] Occasionally, [1] Almost Never

- My instructors and I discussed diversity issues.

- My instructors emphasized the importance of diversity in the workplace.

$1.71(0.83)$
$2.01(0.95)$
$1.32(0.68)$

$\begin{array}{ll}\text { My instructors emphasized the importance of diversity in the workplace. } & 2.01(0.95) \\ - \text { I observed the use of offensive words, behaviors, or gestures directed at students because of their backgrounds or identities. } & 1.32(0.68)\end{array}$

-I felt intimidated by some of my engineering and/or computer science instructors.

Open channels of communication exist between faculty and students.

- Students are treated equitably and fairly by faculty in my major.

- Course content reflects contributions of all engineers or computer scientists, including women and people of color, etc.

- Students of all backgrounds/identities participate in class (in discussion, in-class assignments, team projects, etc.).

- I received positive feedback from instructors that I can do well in engineering and/or computer science courses.

- My engineering and/or computer science courses had an open and positive atmosphere.
$2.15(0.96)$

$2.87(0.85)$

$3.20(0.83)$

$3.20(0.83)$

$2.98(0.89)$
$3.08(0.88)$

$2.69(0.99)$

$2.98(0.86)$
$1.97(0.92) \quad 2.43(0.97) \quad 0.46(0.002)$

$\begin{array}{lll}3.16(0.81) & 2.73(0.95) & 0.43(0.002)\end{array}$

$3.22(0.86) \quad 2.89(0.90) \quad 0.33(0.004)$

$3.11(0.80) \quad 2.82(0.94) \quad 0.29(0.01)$ 
Table 2, continued:

\begin{tabular}{|c|c|c|c|c|c|c|c|}
\hline & \multirow[b]{2}{*}{$\begin{array}{l}\text { Population } \\
\text { Mean (St.Dev) }\end{array}$} & \multicolumn{3}{|c|}{ Gender } & \multicolumn{3}{|c|}{ Race } \\
\hline & & $\begin{array}{l}\text { Male } \\
\text { Mean (St.Dev) }\end{array}$ & $\begin{array}{l}\text { Female } \\
\text { Mean (St.Dev) }\end{array}$ & $\begin{array}{l}\text { Effect Size } \\
\text { (p value) }\end{array}$ & $\begin{array}{l}\text { Non-URM } \\
\text { Mean (St.Dev) }\end{array}$ & $\begin{array}{l}\text { URM } \\
\text { Mean (St.Dev) }\end{array}$ & $\begin{array}{l}\text { Effect Size } \\
(\mathrm{p} \text { value })\end{array}$ \\
\hline \multicolumn{8}{|l|}{ Faculty Interactions, continued } \\
\hline \multicolumn{8}{|l|}{$\begin{array}{l}\text { For the following items please indicate your level of agreement: [7] Strongly agree, [6] Agree, [5] Somewhat agree, [4] Neither } \\
\text { agree nor disagree, [3] Somewhat disagree, [2] Disagree, [1] Strongly disagree }\end{array}$} \\
\hline I feel comfortable asking questions in my engineering and/or computer science class & $5.43(1.5)$ & $5.73(1.31)$ & $5.03(1.61)$ & $0.70(0.003)$ & & & \\
\hline I feel comfortable contributing to class discussions in my engineering and/or computer science class & $5.45(1.52)$ & $5.78(1.30)$ & $4.98(1.69)$ & $0.80(0.001)$ & & & \\
\hline The professors in my engineering and/or computer science classes respect me & $5.79(1.22)$ & & & & & & \\
\hline $\begin{array}{l}\text { I would feel comfortable asking a professor in my engineering and/or computer science classes for help if I did not understand course- } \\
\text { related material }\end{array}$ & $5.75(1.33)$ & $5.95(1.17)$ & $5.51(1.47)$ & $0.45(0.01)$ & & & \\
\hline When I interact with professors at this college, I feel they care about how I'm doing & $5.43(1.51)$ & & & & & & \\
\hline Professors at this college make me question whether I should be here & $2.86(1.8)$ & & & & & & \\
\hline \multicolumn{8}{|l|}{ Professional Identity } \\
\hline \multicolumn{8}{|l|}{$\begin{array}{l}\text { Please indicate the degree to which each factor has positively influenced your decision to stay in your major. [4] Significant Influence, } \\
\text { [3] Moderate Influence, [2] Small Influence, [1] No Influence }\end{array}$} \\
\hline - Ability to find satisfactory co-ops and/or internships & $2.39(1.09)$ & & & & & & \\
\hline - My personal abilities/talents are a good "fit" for the requirements in my major & $1.6(0.79)$ & & & & & & \\
\hline - Confident of succeeding in engineering or computer science future classes & $1.84(0.91)$ & & & & & & \\
\hline - Sufficient opportunities for financial aid or scholarships & $2.39(1.12)$ & & & & $2.48(1.11)$ & $1.97(1.01)$ & $0.51(0.02)$ \\
\hline - Satisfactory performance on my grades in engineering or computer science & $1.83(0.93)$ & & & & & & \\
\hline \multicolumn{8}{|l|}{$\begin{array}{l}\text { How often did the following occur in your experience as a student in [computer science or engineering] courses? [4] Almost Always, } \\
\text { [3] Offen, [2] Occasionally, [1] Almost Never }\end{array}$} \\
\hline $\begin{array}{l}\text { - I felt like a valued member of the engineering and/or computer science community at my university. } \\
\text { - My courses emphasized acceptance of and respect for differences (of opinion, background, etc.). }\end{array}$ & $\begin{array}{l}2.66(0.97) \\
2.68(0.96)\end{array}$ & $2.80(0.95)$ & $2.47(0.98)$ & $0.33(0.008)$ & & & \\
\hline $\begin{array}{l}\text { How much stress do you feel in completing your coursework right now? [5] Extreme stress, [4] Significant stress, [3] Reasonable } \\
\text { stress, [2] Some stress, [1] No stress }\end{array}$ & $3.51(0.98)$ & $3.33(0.98)$ & $3.79(0.90)$ & $0.46(0.003)$ & & & \\
\hline $\begin{array}{l}\text { How well are you meeting the workload demands of your coursework? [5] Easily Meet All, [4] Meet All With Difficulty, [3] Cannot } \\
\text { Meet Some, [2] Cannot Meet Most, [1] Cannot Meet Any }\end{array}$ & $3.89(0.62)$ & & & & & & \\
\hline $\begin{array}{l}\text { At the present time, how confident are you that you will earn a bachelor's degree in engineering or computer science? [5] Very } \\
\text { confident, [4] Somewhat confident, [3] Neither confidentunconfident, [2] Not very confident; [1] Not at all confident }\end{array}$ & $4.73(0.62)$ & & & & & & \\
\hline \multicolumn{8}{|l|}{$\begin{array}{l}\text { Rate yourself on each of the following traits as compared to your classmates. [5] Highest 10\%, [4] Above Average, [3] Average, [2] } \\
\text { Below Average, [1] Lowest 10\% }\end{array}$} \\
\hline - Math ability & $3.90(0.85)$ & & & & & & \\
\hline - Science ability & $3.79(0.79)$ & $3.94(0.78)$ & $3.59(0.77)$ & $0.35(0.007)$ & & & \\
\hline - Engineering ability & $3.73(0.87)$ & $3.97(0.81)$ & $3.39(0.85)$ & $0.59(0.001)$ & & & \\
\hline - Overall academic abilities & $3.88(0.75)$ & & & & & & \\
\hline - Ability to apply math and science principles in solving real world problems & $3.82(0.85)$ & $4.00(0.83)$ & $3.57(0.83)$ & $0.44(0.001)$ & & & \\
\hline \multicolumn{8}{|l|}{ Family Supports } \\
\hline $\begin{array}{l}\text { How often in your day-to-day life at [college] do you think about your financial circumstances? [5] Very offen, [4] Offen, [3] } \\
\text { Sometimes, [2] Rarely, [1] Never }\end{array}$ & $3.22(1.32)$ & $3.06(1.27)$ & $3.43(1.39)$ & $0.36(0.04)$ & & & \\
\hline Do you have any concern about your ability to finance your college education? [3] Major concerns, [2] Some concerns, [1] None & $2.53(0.50)$ & & & & & & \\
\hline
\end{tabular}




\section{Conclusions}

Comparing the results of our two study methodologies, we see distinct themes that emerge from the "tight lens" focus group approach versus the "wide lens" survey. In the focus groups, microaggressions against women and URM students from both majority peers and faculty were strongly prevalent; however, in the survey, the reported incidence of micro-aggressions was relatively rare and countered by fairly strong statements from both majority and minority students about inclusive course atmosphere. This is not to suggest that even rare instances of micro-aggressions are to be tolerated in our classrooms, and stronger evidence of their persistence and detrimental effects are presented in the literature [5,6]. Similarly, the "tight lens" of our focus group study may have led us to initially overlook disparities for women students in terms of professional identity, peer interactions, and faculty interactions. The survey results highlighted deficiencies in self-efficacy for women students that are highly consistent with the literature $[5,6]$ but not emergent from the focus group data. Women students were less comfortable contributing to group discussions and asking faculty for assistance, neither of which were reported concerns for URMs who were actually more comfortable approaching faculty.

The differences in our findings offer implications for the cautionary nature of studies of diversity in postsecondary education. More specifically, our findings suggest that the "lens" - the methods of data collection in a study and the units of analysis - does impact principal study findings, even from the same undergraduate population. Given that the findings of our study were used to drive strategic planning for diversity and inclusion efforts at our institution, we caution against relying on a single methodology - however consistent the findings appear to be with existing literature to set your course of action and/or generalize to larger populations. We most strongly advise a mixed methods approach that affords different levels of analysis that can be used to triangulate findings. By doing so, the validity and reliability of the recommendations and implications can be strengthened through maximum information and perspective, corroboration of data, and reduction of bias $[18,19]$. Such methods might be used to clarify complex social, cultural, and/or political phenomena [20] such as the lack of diversity in particular engineering fields. 


\section{References}

[1] S. Cheryan, S. A. Ziegler, A. K. Montoya, and L. Jiang, "Why are some STEM fields more gender balanced than others?” Psychol Bull, vol.143, no.1, pp.1-135, Jan. 2017.

[2] C. E. Foor, S. E. Walden. and D. A. Trytten, "I wish that I belonged more in this whole engineering group: Achieving individual diversity," Journal of Engineering Education, vol. 96, no. 2, pp. 103-115, Apr. 2007.

[3] R.T. Palmer, D.C. Maramba, \& T. E. Dancy, "A qualitative investigation of factors promoting the retention and persistence of students of color in STEM," The Journal of Negro Education, vol. 80, no. 4, pp. 491-504, Fall. 2011.

[4] K.D. Kendricks, K.V. Nedunuri, and A.R. Arment, "Minority student perceptions of the impact of mentoring to enhance academic performance in STEM discipline," Journal of STEM Education: Innovations and Research, vol.14, no.2, pp. 38-46, Apr-Jun. 2013.

[5] R. M. Marra, K. A. Rodgers, D. Shen, and B. Bogue, "Leaving engineering: A multi-year single institution study," J Eng Educ, vol. 101, no.1, pp. 6-27, Jan. 2012.

[6] M. Meyer and S. Marx, "Engineering dropouts: A qualitative examination of why undergraduates leave engineering," J Eng Educ, vol. 103, no. 4, pp. 525-548, Oct. 2014.

[7] S.D. Museus, R.T. Palmer, R.J. Davis, and D. Maramba (Eds.), "Factors that influence success among racial and ethnic minority college students in the STEM circuit," in "Racial and Ethnic Minority Student Success in STEM Education: ASHE Higher Education Report," John Wiley \& Sons, San Francisco, CA, USA, 2011, vol. 36.

[8] A. S. Bix. Girls Coming to Tech! A History of American Engineering Education for Women. Cambridge, MA: MIT Press, 2014.

[9] M.W. Ohland, C. E. Brawner, M. M. Camacho, R. A. Layton, R. A. Long, S. M. Lord, and

"Race, gender, and measures of success in engineering education," J Eng Educ, vol. 100, no. 2, pp. 225-252, Apr. 2011.

[10] M. H. Wasburn, "Race, gender, and measures of success in engineering education," J Eng Educ, vol. 100, no. 2, pp. 225-252, Apr. 2011.

[11] Barnes TN, Zhang X, Trauth AE, Enszer J, Rooney S, Davidson R, Buckley JM. How granular is the problem? A discipline-specific focus group study of factors affecting underrepresentation in engineering undergraduate programs. 2018 Proceedings of the American Society for Engineering Education.

[12] C. E. Foor and S. E. Walden, 'Imaginary engineering' or 're-imagined engineering': Negotiating gendered identities in the borderland of a college of engineering." NWSA Journal, vol. 21, no. 2, pp 41-64, Summer 2009.

[13] Creswell, J. W., \& Plano Clark, V. (2011). Designing and conducting mixed methods research. Thousand Oaks, CA: Sage Publications, Inc.

[14] Merriam, S. B. (1998). Qualitative research and case study applications in education. San Francisco, CA: Jossey-Bass.

[15] D. Chachra and D. Kilgore, "Exploring gender and self-confidence in engineering students: A multi-method approach," Cent. Adv. Eng. Educ., Washington, USA, Tech Rep. Apr. 2009.

[16] H. Chen, K. Donaldson, O. Eriş, D. Chachra, G. Lichtenstein, S. D. Sheppard, and G. Toye, "From PIE to APPLES: The evolution of a survey instrument to explore engineering student pathways," in 2008 ASEE Proceedings.

[17] D. Baker, S. Krause, and S. Y. Purzer, "Developing an instrument to measure tinkering and technical self-efficacy in engineering," presented at the 2008 ASEE Annual Conference and Exposition, 2008 
[18] Reams, P., \& Twale, D. (2008). The promise of mixed methods: Discovering conflicting realities in the data. International Journal of Research \& Method in Education, 31(2), 133-142. [19] Wagner, K. D., Davidson, P. J., Pollini, R. A., Strathdee, S. A., Washburn, R., \& Palinkas, L. A. (2012). Reconciling incongruous qualitative and quantitative findings in mixed methods research: Exemplars from research with drug using populations. International Journal of Drug Policy, 23(1), 54-61.

[20] Hart, C. H., Lawrence, F., \& Thomasson, R. (1990). Article Metrics Related Articles Cite Share Request Permissions Explore More Download PDF Measuring Socioeconomic Status in Child Development Research. 